\title{
Analysis Of Risk Factors Oxidative Stress In Obesity Women
}

\section{Analisis Faktor Risiko Terjadinya Stres Oksidatif Pada Wanita Obesitas}

Alpha Olivia Hidayati ${ }^{1}$, Ernawati Hardani ${ }^{2}$

\section{Abstract}

Obesity is a condition of imbalance in the number of calories entered by the number of calories where the excess is heaped up as body fat. Obesity followed by an increase in fat metabolism will cause Reactive Oxygen Species (ROS) production to increase. This condition causes oxidative stress. Indicators of oxidative stress can be observed from plasma levels of Malondialdehyde (MDA). This study aims to determine the risk factors for oxidative stress in obese women.

The results of this study indicate that high fat intake ( $>60 \mathrm{~g} /$ day) is at risk of increasing MDA-P levels twice. Low fiber consumption ( $<30 \mathrm{gr} /$ day) gives the risk of an increase in MDA-P levels of 2.09 times. Poor physical activity is a risk factor for MDA-P increase of 1.15 times. High cholesterol (> 200mg / I) and LDL (> $130 \mathrm{mg} / \mathrm{l}$ ) and low HDL ( $\leq 45 \mathrm{mg} / \mathrm{dl}$ ) levels are at risk of increasing MDA-P levels by 1.02 times (cholesterol), 1.13 (LDL) ) and 1.12 (HDL).

Based on this study it can be concluded that high fat intake, low fiber intake, low physical activity, high cholesterol and HDL levels and low HDL levels are risk factors for oxidative stress.

Keywords: obesity, oxidative stress, MDA-P, nutritional intake, physical activity, lipid profile

\section{Intisari}

Obesitas merupakan suatu kondisi ketidakseimbangan jumlah kalori yang masuk dengan jumlah kalori dimana kelebihannya ditimbun sebagai lemak tubuh. Obesitas yang diikuti dengan peningkatan metabolisme lemak akan menyebabkan produksi Reactive Oxygen Species (ROS) meningkat. Kondisi ini menyebabkan terjadinya stres oksidatif. Indikator terjadinya stres oksidatif dapat diamati dari kadar Malondialdehida (MDA) plasma. Penelitian ini bertujuan untuk mengetahui faktor risiko terjadinya stres oksidatif pada wanita obesitas.

Hasil penelitian ini menunjukan bahwa asupan lemak yang tinggi ( $>60 \mathrm{~g} /$ hari) berisiko peningkatan kadar MDA-P sebanyak dua kali. Konsumsi serat yang rendah (<30 gr/hari) memberikan rlsiko terjadinya peningkatan kadar MDA-P sebesar 2,09 kali. Aktifitas fisik yang kurang menjadi faktor risiko peningkatan MDA-P sebanyak 1,15 kali. Kadar kolesterol (>200mg/l) dan LDL (>130 mg/l) yang tinggi dan kadar HDL ( $\leq 45 \mathrm{mg} / \mathrm{dl}$ ) yang rendah beresiko peningkatan kadar MDA-P sebanyak 1,02 kali (kolesterol), 1,13 (LDL) serta 1,12 (HDL).

Afiliasi Penulis

1 | STIKes Guna Bangsa Yogyakarta

2 | Puskesmas Jetis Kota Yogyakarta

\section{Korespondensi kepada}

A.O. Hidayati

alphaoliviahidayati@gmail.com
Berdasarkan penelitian ini dapat disimpulkan bahwa asupan lemak yang tinggi, asupan serat yang rendah, aktifitas fisik yang rendah, kadar kolesterol dan HDL yang tinggi serta kadar HDL yang rendah menjadi faktor risiko terjadinya stres oksidatif.

Kata kunci: obesitas, stres oksidatif, MDA-P, asupan gizi, aktifitas fisik, profil lipid 


\section{Pendahuluan}

Obesitas merupakan suatu kondisi ketidakseimbangan jumlah kalori yang masuk dengan jumlah kalori yang digunakan dalam bentuk energi sehingga dalam kurun waktu tertentu kelebihannya ditimbun sebagai lemak tubuh [1]. Obesitas merupakan penyakit degeneratif yang jumlahnya semakin meningkat. Menurut data RISKESDAS 2013, prevalensi obesitas di Indonesia mencapai 32,9\%, dimana Daerah Istimewa Yogyakarta masuk ke dalam enam belas provinsi dengan prevalensi obesitas diatas prevalensi obesitas nasional [2]

Obesitas menjadi faktor resiko terjadinya penyakit degeneratif yang lain, seperti Jantung, hipertensi dan Diabetes militus. Pada orang dengan obesitas, biasanya memiliki kadar trigliserida di dalam darah yang tinggi dengan kadar HDL yang relatif rendah [3]. Obesitas yang diikuti dengan peningkatan metabolisme lemak akan menyebabkan produksi Reactive Oxygen Species (ROS) meningkat. Peningkatan ROS pada jaringan adiposa berakibat terganggunya keseimbangan reaksi reduksi oksidasi sehingga terjadi penurunan enzim antioksidan di dalam darah [4]. Pada kondisi ini kadar oksidan lebih dominan. Oksidan adalah senyawa reaktif yang dapat memindahkan elektron dari molekul lain dan dapat menimbulkan oksidasi pada molekul tersebut. Kondisi ini disebut sebagai stres oksidatif [5]. Beberapa dampak yang ditimbulkan dengan terjadinya stres oksidatif adalah oksidasi DNA yang dapat menginisiasi terjadinya kanker, terjadinya arterosklerosis dan merusak struktur membran sel yang berakibat penurunan fungsi organel sel [6].

Jika lipid yang memiliki rantai karbon ganda bereaksi dengan oksidan, maka akan terjadi peroksidasi lipid [7,8]. Lipid hidroperoksida merupakan produk utama dari peroksidasi lipid. Struktur ini tidak stabil sehingga dapat dengan mudah berubah menjadi malondialdehid (MDA), 4hidroksi-2-noneal(4-HNE) dan beberapa bentuk aldehid lain. Sifat MDA yang lebih stabil dibandingkan dengan produk aldehid lain menyebabkan senyawa ini lebih sering dipakai sebagai petanda stres oksidatif [9]. Kadar malondialdehyde plasma (MDA-P) pada individu sehat adalah 0,8 $\pm 0,20 \mu \mathrm{mol} / \mathrm{L}$ [4].

Penelitian sebelumnya menunjukan bahwa pada orang yang mengalami obesitas dapat terjadi peningkatan peroksida lipid endogen. Hal ini dapat dilihat dari kadar MDA-P pada kelompok obesitas sebesar 2,00 $\pm 0,77$ dan non obesitas sebesar $1,63 \pm 0,14$. Hal ini menunjukan adanya hubungan erat antara tingkat kerusakan metabolik bersamaan dengan gangguan stres oksidatif [3]. Pada mekanisme patalogis diketahui bahwa akumulasi lemak dan resistensi insulin pada orang dengan obesitas berperan dalam peningkatan gangguan metabolisme [10]. Pada profil lipid, perubahan LDL menjadi bentuk LDL teroksidasi yang diperantarai oleh radikal bebas dapat menyebabkan terjadinya kerusakan dinding arteri. Selain itu, kadar kolesterol dan trigliserida yang tinggi di dalam darah dapat menjadi faktor resiko terjadinya aterosklerosis dan penyakit jantung [3].

Berdasarkan latar belakang tersebut, perlu dilakukan penelitian untuk mengetahui faktor risiko terjadinya stres oksidatif pada wanita obesitas. Hasil penelitian ini diharapkan dapat menambah pengetahuan klinisi dan dapat menjadi dasar tata laksana pencegahan beberapa penyakit degeneratif yang dipicu oleh terjadinya stres oksidatif.

\section{Metode}

Penelitian ini merupakan penelitian analitik observasional dengan desain cross sectional yang dilaksanakan pada bulan Maret sampai dengan Juli 2018. Penelitian dilakukan di lingkungan Puskesmas Dinas Kesehatan Kota Yogyakarta. Popuplasi penelitian adalah pegawai wanita di puskesmas lingkungan Dinas Kesehatan Kota Yogyakarta.

Subjek penelitian adalah pegawai wanita obesitas di lingkungan Dinas Kesehatan Kota Yogyakarta yang memenuhi kriteria inklusi dan eksklusi penelitian. Kriteria inklusi penelitian adalah wanita usia 35 - 55 tahun, IMT >25, tidak sedang mengkonsumsi obat diet sekurangnya 2 minggu sebelum penelitian, bersedia mengikuti penelitian dan menandatangani informed consent, tidak sedang hamil dan menyusui, tidak mempunyai penyakit jantung, diabetes melitus, 
hipertensi dan ginjal. Kriteria eksklusi penelitian adalah subjek yang merokok. Besar sampel dihitung dengan menggunakan rumus besar sampel dengan nilai standar deviasi 1,3 , tingkat kepercayaan $95 \%$ dan nilai $\alpha=5 \%$ dan diperoleh jumlah sampel minimal 60 sampel. Teknik pengambilan sampel dengan metode Consecutive sampling.

Data karakteristik subjek berupa aktifitas fisik dan penggunaan alat kontrasepsi dilakukan dengan wawancara. Pengukuran aktivitas fisik dilakukan dengan recall aktivitas selama $1 \times 24$ jam yang dilakukan selama dua hari, yaitu hari kerja dan hari libur. Pengukuran dilakukan terhadap jenis aktivitas selama 24 jam dinyatakan dalam PAL (Physical Activity Level) [12]. Penentuan status gizi berdasarkan indikator indeks massa tubuh (IMT) yaitu berat badan dibagi kuadran tinggi badan $\left(\mathrm{kg} / \mathrm{m}^{2}\right)$. Status gizi dikatakan obesitas berdasarkan cut off point untuk asia pasifik yaitu $25 \mathrm{~kg} / \mathrm{m}^{2}$ [13]. Data Asupan gizi diperoleh dengan Food Frequency Questionnnaire (FFQ) yang didasarkan pada nilai AKG (Angka Kecukupan Gizi) untuk asupan karbohidrat, protein, lemak dan serat. Penggunaan alat kontrasepsi hormonal berupa pil KB, suntik KB dan implan sedangkan kontrasepsi non hormonal IUD, steril, dan sistem kalender.

Data profil lipid dan MDA-P diperoleh dari plasma darah subjek. Pemeriksaan MDA-P menggunakan metode uji TBARs (thiobarbituric acid reactive substance) yang dibaca menggunakan spektrofotometer dengan panjang gelombang 532 $\mathrm{nm}$ [35/19dengan cut off yang digunakan adalah $0.8 \mu \mathrm{mol} / \mathrm{L}$. Data profil lipid meliputi Kolesterol (cut off $>200 \mathrm{mg} / \mathrm{dL}$ ), trigliserida (cut off $>150 \mathrm{mg} / \mathrm{dL}$ ), LDL (>130 mg/dL) dan HDL (>45 mg/dL) [14].

Analisis data dilakukan dengan uji Chi Square untuk melihat hubungan antara variabel dependen dan variabel independen serta uji Odds Ratio untuk mengetahui faktor resiko yang berhubungan dengan kadar MDA-P sebagai indikator terjadinya stres oksidatif. Variabel independen yang diamati antara lain asupan gizi (protein, lemak, karbohidrat dan serat), aktifitas fisik dan profil lipid (kolesterol, trigliserida, LDL dan HDL). Sedangkan variabel dependen yang diamati adalah kadar MDA-P. Data yang telah diuji, ditampilkan dalam bentuk tabel.

\section{Hasil \& Pembahasan}

Berdasarkan karakteristik subjek (tabel 1) terlihat bahwa subjek penelitian sebagian besar termasuk ke dalam kriteria obesitas tingkat I (80.3\%) sedangkan sisanya termasuk ke dalam obesitas tingkat II (19.7\%). Sedangkan berdasarkan tingkat aktifitas fisik sebagian besar subjek termasuk memiliki aktifitas fisik yang cukup (57.6\%) dan sisanya termasuk dalam aktifitas fisik kurang (42.4\%). Jika dilihat dari penggunaan alat kontrasepsi, sebagian besar subjek penelitian menggunakan alat kontrasepsi non hormonal $(53,03 \%)$, yaitu IUD, steril dan sistem kalender. Sedangkan sisanya menggunakan KB hormonal, yaitu pil, suntik dan implan. Hasil pengukuran kadar

Tabel 1 | Karakteristik Subjek Penelitian

\section{Jumlah (n)}

Persentase (\%)

Kadar MDA

$\begin{array}{ccc}>0,8 \mu \mathrm{mol} / \mathrm{l} \text { (tidak normal) } & 39 & 59.1 \\ \leq 0,8 \mu \mathrm{mol} / \mathrm{l} \text { (normal) } & 27 & 40.9\end{array}$

Aktivitas Fisik

\begin{tabular}{|c|c|c|c|}
\hline & & & \\
\hline & Kurang & 28 & 42.4 \\
\hline & Cukup & 38 & 57.6 \\
\hline \multicolumn{4}{|l|}{ Penggunaan Alat Kontrasepsi } \\
\hline & hormonal & 31 & 46.96 \\
\hline & non hormonal & 35 & 53.03 \\
\hline \multicolumn{4}{|l|}{ IMT } \\
\hline & $\geq 30 \mathrm{~kg} / \mathrm{m} 2$ & 10 & 19.7 \\
\hline & $25-29.9 \mathrm{~kg} / \mathrm{m} 2$ & 53 & 80.3 \\
\hline
\end{tabular}


Tabel 2 | Distribusi rata - rata kadar asupan gizi dan profil lipid berdasarkan pengelompokan kadar MDA-P

\begin{tabular}{ccccccc} 
Variabel & Jumlah & \multicolumn{5}{c}{ Rata-rata Kadar Asupan Gizi } \\
& $(\%)$ & Energi & Protein & Lemak & Karbohidrat & Serat \\
\hline tidak normal $(>0.8 \mu \mathrm{mol} / \mathrm{l})$ & $39(59)$ & $1890.66 \pm 2.43$ & $60.07 \pm 8.17$ & $65 \pm 4.32$ & $271,38 \pm 1.90$ & $14.48 \pm 0.65$ \\
normal $(\leq 0.8 \mu \mathrm{mol} / \mathrm{l})$ & $27(41)$ & $1935.7 \pm 8.32$ & $66.55 \pm 12.34$ & $66.3 \pm 6.32$ & $268.89 \pm 0.76$ & $12.72 \pm 0.12$
\end{tabular}

Tabel 3 | Hubungan Asupan Gizi dengan kadar MDA plasma

Kadar MDA Plasma

\begin{tabular}{|c|c|c|c|c|c|c|}
\hline & & \multicolumn{2}{|c|}{ Kadar MDA Plasma } & \multirow{3}{*}{ OR } & \multirow{3}{*}{$95 \mathrm{Cl} \%$} & \multirow{3}{*}{$\mathbf{P}$} \\
\hline & & $\begin{array}{l}\text { tidak normal } \\
(>0.8 \mu \mathrm{mol} / \mathrm{l})\end{array}$ & $\begin{array}{c}\text { normal } \\
(\leq 0.8 \mu \mathrm{mol} / \mathrm{l})\end{array}$ & & & \\
\hline \multicolumn{2}{|c|}{ Variabel } & $n(\%)$ & n (\%) & & & \\
\hline \multirow[t]{3}{*}{ Energi } & & & & & & \\
\hline & >1900 KKal & $17(54.8)$ & $14(45.2)$ & \multirow{2}{*}{0.72} & \multirow{2}{*}{$0.27-1.92$} & \multirow{2}{*}{0.68} \\
\hline & $\leq 1900 \mathrm{Kkal}$ & 22 (62.9) & $13(37.1)$ & & & \\
\hline \multicolumn{7}{|l|}{ Protein } \\
\hline & $>57 \mathrm{~g}$ & $24(54.5)$ & $20(45.5)$ & \multirow{2}{*}{0.56} & \multirow{2}{*}{$0.19-1.64$} & \multirow{2}{*}{0.43} \\
\hline & $\leq 57 \mathrm{~g}$ & $15(68.2)$ & $7(31.8)$ & & & \\
\hline \multicolumn{7}{|l|}{ Lemak } \\
\hline & $>60 \mathrm{~g}$ & 27 (64.3) & 15 (35.7) & \multirow{2}{*}{2} & \multirow{2}{*}{$0.65-4.99$} & \multirow{2}{*}{0.38} \\
\hline & $\leq 60 \mathrm{~g}$ & $12(50.0)$ & $12(50.0)$ & & & \\
\hline \multicolumn{7}{|l|}{ Karbohidrat } \\
\hline & $>323 \mathrm{~g}$ & $6(50)$ & $6(50)$ & \multirow{2}{*}{0.64} & \multirow{2}{*}{$0.18-2.24$} & \multirow{2}{*}{0.7} \\
\hline & $\leq 323 \mathrm{~g}$ & 33 (61.1) & 21 (38.9) & & & \\
\hline \multicolumn{7}{|l|}{ Serat } \\
\hline & $\leq 30 \mathrm{~g}$ & $36(61)$ & $23(39)$ & \multirow{2}{*}{2.09} & \multirow{2}{*}{$0.427-10.19$} & \multirow{2}{*}{0.6} \\
\hline & $>30 \mathrm{~g}$ & 3 (42.9) & $4(57.1)$ & & & \\
\hline
\end{tabular}

MDA-P subjek, terlihat bahwa 59,1\% subjek memiliki kadar MDA-P $>0.8 \mu \mathrm{mol} / \mathrm{l}$ sedangkan 40,9\% memiliki kadar MDA-P kurang dari cut off.

Pada penelitian ini (Tabel 3) menunjukan tingginya asupan lemak $(>60$ g) berisiko peningkatan kadar MDA-P sebanyak dua kali. Sedangkan asupan karbohidrat dan protein tidak menunjukan sebagai faktor risiko terjadinya peningkatan kadar MDA-P. Pada penelitian ini, asupan karbohidrat, lemak, protein dan serat tidak menunjukan adanya hubungan dengan kadar MDA$P(P>0,05)$. Rata - rata jumlah asupan makanan subjek dengan kadar MDA-P >0.8 $\mu \mathrm{mol} / \mathrm{l}$ (Tabel 2) menunjukan asupan energi, protein, dan lemak yang cukup tinggi, yaitu energi $(1935 \pm 8,32)$, protein $(66,55 \pm 12,34)$, dan lemak $(66,30 \pm 6,32)$.

Kondisi ini menunjukan bahwa asupan lemak dan protein yang tinggi berakibat peningkatan kadar MDA-P subjek. Hal ini dikarenakan asam amino banyak yang diubah menjadi Asetil KoA yang kemudian disintesis menjadi trigliserida. Dalam penelitian yang telah dilakukan, dinyatakan bahwa asupan protein hewani, terutama daging merah mempunyai hubungan yang positif dengan kejadian dislipidemia sedangkan konsumsi protein nabati menujukan hasil yang sebaliknya [15]. Asupan lemak berlebih juga dapat meningkatkan kadar lemak darah sehingga akan meningkatkan kadar kolesterol dan trigliserida. Asupan karbohidrat berlebih juga dapat meningkatkan kadar trigliserida [16]. Hal ini sejalan dengan penelitian yang menunjukan bahwa asupan karbohidrat berlebih dapat meningkatkan prevalensi hipertrigliseridemia sebesar 58\% dan rendahnya kadar HDL sebesar 43\% [17]. Peningkatan kadar asam lemak bebas dalam tubuh yang berkonjugasi dengan ROS (radikal bebas) 
Tabel 4 | Hubungan Aktivitas Fisik dengan kadar MDA plasma

Kadar MDA Plasma

\begin{tabular}{|c|c|c|c|c|c|c|}
\hline & & & \multirow{3}{*}{ OR } & \multirow{3}{*}{$95 \mathrm{Cl} \%$} & \multirow{3}{*}{$\mathbf{P}$} \\
\hline & & $\begin{array}{l}\text { tidak normal } \\
(>0.8 \mu \mathrm{mol} / \mathrm{I})\end{array}$ & $\begin{array}{c}\text { normal } \\
(\leq 0.8 \mu \mathrm{mol} / \mathrm{I})\end{array}$ & & & \\
\hline \multicolumn{2}{|c|}{ Variabel } & n (\%) & n (\%) & & & \\
\hline \multirow[t]{3}{*}{ Aktivitas Fisik } & & & & & & \\
\hline & Kurang & $23(60.5)$ & 15 (39.5) & \multirow{2}{*}{1.15} & \multirow{2}{*}{$0.43-3.10$} & \multirow{2}{*}{0.98} \\
\hline & Cukup & $16(57.1)$ & 12 (42.9) & & & \\
\hline
\end{tabular}

Tabel 5 | Hubungan Profil Lipid dengan kadar MDA plasma

\section{Kadar MDA Plasma}

\begin{tabular}{|c|c|c|c|c|c|c|}
\hline & & \multicolumn{2}{|c|}{ Kadar IVIDA PIasma } & \multirow{3}{*}{ OR } & \multirow{3}{*}{$95 \mathrm{Cl} \%$} & \multirow{3}{*}{$\mathbf{P}$} \\
\hline & & $\begin{array}{l}\text { tidak normal } \\
(>0.8 \mu \mathrm{mol} / \mathrm{I})\end{array}$ & $\begin{array}{c}\text { normal } \\
(\leq 0.8 \mu \mathrm{mol} / \mathrm{I})\end{array}$ & & & \\
\hline \multicolumn{2}{|c|}{ Variabel } & n (\%) & n (\%) & & & \\
\hline \multicolumn{7}{|l|}{ Kolesterol } \\
\hline & $>200 \mathrm{mg} / \mathrm{dL}$ & $20(58.8)$ & $14(41.2)$ & \multirow{2}{*}{1.02} & \multirow{2}{*}{$0.38-2.73$} & \multirow{2}{*}{1,00} \\
\hline & $\leq 200 \mathrm{mg} / \mathrm{dL}$ & $19(59.4)$ & $13(40.6)$ & & & \\
\hline \multicolumn{7}{|l|}{ Trigliserida } \\
\hline & $>150 \mathrm{mg} / \mathrm{dL}$ & 31 (64.6) & $17(35.4)$ & \multirow{2}{*}{0.44} & \multirow{2}{*}{$0.146-1.32$} & \multirow{2}{*}{0.23} \\
\hline & $\leq 150 \mathrm{mg} / \mathrm{dL}$ & $8(44.4)$ & $10(55.6)$ & & & \\
\hline \multicolumn{7}{|l|}{$L D L$} \\
\hline & $>130 \mathrm{mg} / \mathrm{dL}$ & $31(58.8)$ & $22(41.5)$ & \multirow{2}{*}{1.13} & \multirow{2}{*}{$0.33-3.93$} & \multirow{2}{*}{1,00} \\
\hline & $\leq 130 \mathrm{mg} / \mathrm{dL}$ & $8(61.5)$ & $5(38.5)$ & & & \\
\hline \multicolumn{7}{|l|}{$H D L$} \\
\hline & $\leq 45 \mathrm{mg} / \mathrm{dL}$ & $17(60.7)$ & $11(39.3)$ & \multirow{2}{*}{1.12} & \multirow{2}{*}{$0.42-3.04$} & \multirow{2}{*}{1,00} \\
\hline & $>45 \mathrm{mg} / \mathrm{dL}$ & 22 (57.9) & $16(42.1)$ & & & \\
\hline
\end{tabular}

menyebabkan terjadinya stres oksidatif yang berimplikasi pada peningkatan kadar MDA-P.

Hasil penelitian menunjukan konsumsi serat yang rendah (Tabel 2 ) dengan cut off $<30 \mathrm{gr} /$ hari memberikan resiko terjadinya peningkatan kadar MDA-P sebesar 2,09 kali. Pada penelitian lain menunjukan bahwa konsumsi serat dapat menurunkan kadar kolesterol dan LDL 6-15\%. Hal ini dikarenakan serat mampu mengurangi penumpukan kolesterol dalam hati dan mengurangi indeks glikemik makanan sehingga menurunkan kejadian dislipidemia [18]. Konsumsi serat dapat menurunkan terjadinya peroksidasi lipid yang dtunjukan dengan penurunan kadar MDA-P pada subjek penelitian. Konsumsi serat terbukti dapat memperbaiki kadar glukosa di dalam darah yang diikuti dengan penurunan kadar MDAP. Hal ini ditunjukan oleh penelitian yang memperlihatkan bahwa pemberian serat berupa pektin pada tikus dapat menurunkan kadar MDA-P $(p<0,05)$ [19]. Hasil penelitian ini menunjukan bahwa konsumsi serat tidak memberikan hubungan yang bermakna terhadap kadar MDA-P. Hal ini dimungkinkan cut off yang digunakan (>30 $\mathrm{g} /$ hari) belum mampu memberikan gambaran asupan yang cukup untuk menurunkan terjadinya stres oksidatif dilihat dari penurunan kadar MDA-P.

Pada penelitian ini menunjukan kurangnya aktifitas fisik menyebabkan peningkatan resiko terjadinya stres oksidatif melalui peningkatan kadar MDA-P sebanyak satu kali (Tabel 4). Kondisi ini dimungkinkan terjadi karena aktifitas fisik yang cukup, berdampak pada peningkatan aktifitas antioksidan sehingga stes oksidatif dapat dicegah, akibatnya peroksidasi lipid dapat menurun [20]. Hasil ini didukung dengan penelitian yang telah dilakukan pada subjek penderita diabetes mellitus tipe 2 dimana latihan fisik yang dilakukan 3 kali dalam satu minggu selama 45 menit, mampu menurunkan kadar MDA-P secara bermakna 
$(p<0,05)[4]$. Penelitian lain menunjukan bahwa kelompok responden yang melakukan olah raga teratur dan aktif secara fisik mempunyai kadar HDL yang lebih tinggi dibandingkan kelompok lain yang memiliki gaya hidup sedenter [21]. Latihan fisik secara teratur dapat memperbaiki hiperglisemia melalui peningkatan sensitivitas insulin dan aktivitas enzim mitokondrial [22]. Namun demikian, pada penelitian ini, aktifitas fisik tidak menunjukan adanya hubungan dengan kadar MDAP. Hal ini dimungkinkan karena, pengukuran aktifitas fisik subjek penelitian belum mampu memberikan penilaian aktifitas fisik yang sebenarnya dari subjek penelitian.

Penelitian ini menunjukkan bahwa pada kadar kolesterol yang tinggi berisiko peningkatan kadar MDA-P sebanyak 1,02 kali. Demikian pula dengan kadar LDL yang tinggi berisiko meningkatkan kadar MDA-P sebanyak 1,13. Sedangkan kadar HDL yang rendah beresiko terjadinya peningkatan kadar MDA-P sebanyak 1,12 kali (Tabel 5). Kondisi ini didukung dengan rata - rata kadar kolesterol, trigliserida dan LDL yang tinggi, yaitu kolesterol $(201,2 \pm 2,45)$, trigliserida $(143,48 \pm 13,24)$, dan LDL $(111,2 \pm 16,67)$. Tingginya kadar profil lipid dikarenakan konsumsi protein dan lemak yang tinggi. Sedangkan peningkatan kadar MDA-P dimungkinkan karena terjadi reaksi antara asam lemak bebas yang berlebih dengan radikal bebas (ROS) yang membentuk peroksidasi lipid [6]. Peningkatan peroksidasi lipid dalam tubuh tercermin dari kadar MDA-P dalam plasma yang tinggi, walaupun secara statistik kadar kolesterol, trigliserida dan LDL tidak menunjukan adanya hubungan dengan kadar MDA-P( $P>0,05)$. Pada penelitian ini kadar kolesterol, trigliserida, LDL dan HDL tidak menunjukan adanya hubungan dengan kadar MDA-P $(P>0,05)$.

\section{Kesimpulan}

Berdasarkan penelitian ini dapat disimpulkan bahwa asupan lemak yang tinggi, asupan serat yang rendah, aktifitas fisik yang rendah, kadar kolesterol dan HDL yang tinggi serta kadar HDL yang rendah menjadi faktor risiko terjadinya stres oksidatif.

\section{Bibliografi}

1. Winarsi H, Siwi $P$ M, Agus $P, 2011$, Profil lipid, peroksidasi lipid dan status inflamatif wanita, Jurnal Kesehatan Masyarakat Nasional, Vol 5, № 5, 212-217

2. Kemenkes, 2013, Riset Kesehatan Dasar (RISKESDAS), Badan Penelitian dan Pengembangan Kesehatan, Kementrian Kesehatan RI,Hal 225-226.

3. Fernandez SA, Madrigal SE, Bautista M, Esquivel SJ, Morales GA, Esquivel CC, Durante MI, Sanchez RG, Valadez VC, Morales GJA, 2011, Inflammation, oxidative stress, and obesity, Int J Mol Sci, Vol 12, No 5, PP 3117-32.

4. Nazarina, Reviana, \& Yunita D S., 2013, Faktor - faktor yang berhubungan dengan kadar malondialdehyde plasma pada penyandang diabetes mellitus tipe 2, Jurnal Gizi Klinik Indonesia, Vol. 9, No. 3, hal 136-146.

5. Anggraeni S, Trisniartami S, Yulianto L, 2017 Perbedaan kadar Malondialdehid (MDA) sebagai petanda stres oksidatif pada berbagai derajat akne vulgaris. Berkala IImu Kesehatan Kulit dan Kelamin, Vol 29, No 1, Hal 36 - 43.

6. Balgis \& Binar $P, 2013$, Pengaruh pemberian angkak (red yeast rice) terhadap kadar kolesterol total dan trigliserida pada wanita penderita hiperlipidemia, Journal of Nutrition College, Vol 2, No 4, Hal 571-577.

7. Ayala A, Munoz MZ, Arguelles S, 2014, Lipid peroxidation: production, metabolism, and signaling mechanism of malondialdehyde and 4 hydroxy-2nonenal. Oxid Med Cell Longev, Vol 112, PP 21-28.

8. Grotto D, Maria LS, Valentini J, Paniz C, Garcia GS, Pomblum VJ, 2009, Importance of the lipid peroxidation biomarker and methodological aspects for malondialdehyde quatification, Quimm Nova, Vol 32, No 1, PP 169-174.

9. Salvayre AN, Coatrieux C, Ingueneau C, Salvayre R, 2008, Advanced lipid peroxidation end product in oxidative damage to proteins. Potensial role in disease and therapeutic prospects for the inhibitors. British Journal of Pharmacology, Vol 156, PP 6-20.

10. Kasim S, Mansur A, Agus S, Joko W, 2012, Hubungan obesitas dan hipertrigliseridemia dengan risiko perlemakan hati pada pasien di Makasar. Jurnal Farmasi Klinik Indonesia, Vol 1 No 4, Hal 136-146.

11. Suryana \& Yulia F., 2017, Hubungan aktifitas fisik dengan IMT dan komposisi lemak tubuh, Jurnal AcTion: Aceh Nutrition Journal, Vol 2, № 2, hal 114119.

12. WHO, 2000, The Asia Pasific perspective: redefining obesity and its treatment. IASP International Association for The Study of Obesity. PP 15 - 18

13. Rahmawansa S \& Sany, 2009, Dislipidemia sebagai 
risiko utama penyakit jantung koroner (PJK). Cermin Dunia Kedokteran (CDK), Vol 36, No 3. hal 181-184.

14. Delavar MA, Lye MS, Hassan, Khor GL, \& Hanachi P, 2011, Physical activity, nutrition, and dyslipidemia in middle-age women. Iranian J Publ. Health. Vo. 40, No 4, PP 89-98.

15. Jellinger SP,Yehuda $H, P a u l D R$, Zachary TB, Vivian AF, Alan JG, George G, Chris K,2017, American Association of Clinical Endocrinologist (AACE) Guidelines for management of dyslipidemia and prevention of artherosclerosis, Endocrine Practice, Vol 18, No 1, PP 20 - 25.

16. Song, Su Jin, Jung Eun Lee, Hee-Young Paik, Min Sun Park \& Yoon Su Song, 2012, Dietary patterns based on carbohydrate nutrition are associated with the risk for diabetes and dyslipidemia, Nutrition Research and practice, Vol 6, № 4, PP 349-356.

17. Papathanasopoulos, Anthanasios, \& Michael C, 2010, Dietary fiber supplements: Effects in obesity and metabolic syndrome and relationship to gastrointestinal functions. National Institues of Health; Rochester: Gastroenterology, Vol 138, № 1, PP 6572.

18. Shafaeizadeh S, Jamalian J, Owji AA, Azadbakht L, Ramezani R, Karbalaei N, Rajaeifard A, Tabatabai N, 2011, The effect of consuming oxidized oil supplemented with fiber on lipid profiles in rat model, $J$ Res Med Sci, Vol 16, No 12, PP 1541 - 9.

19. Gordon LA, Morrison EY, McGrowder DA, Young R, Fraser YT, Zamora EM, Alexander Lindo RL, Irving $R R, 2008$, Effect of exercise theraphy on lipid profile and oxidative stress indicators in patients with type 2 diabetes. BMC Complement Altern Med.vol 8. PP 21.

20. Kokkinos \& Peter, 2010, Physical activity and cardiovasculer disease prevention, Massacusetts: John and Bartlett Publishers.

21. Lauza IR, Short DK, Short KR, Raghavalaimal S, Basu R, Joyner MJ, McConnel JP, Nair KS, 2008, Endurence exercise as Countermeasure for aging. Diabetes Journal, Vol. 57, No. 11, PP 2933-42.

22. Balgis \& Binar $P, 2013$, Pengaruh pemberian angkak (red yeast rice) terhadap kadar kolesterol total dan trigliserida pada wanita penderita hiperlipidemia, Journal of Nutrition College, Vol 2, No 4, Hal 571-577. 